\title{
JoECCE
}

Journal of Early Childhood and Character Education

Vol 1, No : 2, 2021

\section{Upaya Pengembangan Motorik Kasar Melalui Kegiatan Menari Di RA Imama Kedungpane Mijen Semarang}

\author{
Mursid Mursid \\ mursid@walisongo.ac.id \\ Syafa'atun Nabilah \\ Syafanabilah5@gmail.com \\ PIAUD, Fakultas Ilmu Tarbiyah dan Keguruan, \\ UIN Walisongo Semarang
}

\begin{abstract}
This article contains gross motor development in children through learning to dance in the teaching and learning process. The place of research was carried out in group B1 at RA IMAMA Kedungpane Mijen, the method in this study used the type of classroom action research (CAR) which was carried out in 2 with each cycle containing planning, implementation, observation and reflection. This research was conducted with a total of 27 children. The instrument of this research is using observation guide and documentation guide.

The results of the study concluded that: the pre-action research resulted in $32.22 \%$, then in the first cycle there was an increase in the average gross motor development reaching $55.74 \%$ and the second cycle an average gross motor development reaching $84.44 \%$. With these results indicate that this research is successful because it has reached the target of research indicators of $75 \%$.
\end{abstract}

Keywords: Gross Motor, dance activities 


\section{Abstrak}

Artikel ini Berisi mengenai perkembangan motorik kasar pada anak melalui kegiatan belajar menari dalam proses belajar mengajar. Tempat penelitian dilaksanakan pada kelompok B1 di RA IMAMA Kedungpane Mijen, Metode dalam penelitian ini menggunakan jenis penelitian penelitian tindakan kelas (PTK) yang dilakukan dalam 2 dengan masingmasing siklus memuat perencanaan, pelaksanaan, observasi dan refleksi. Penelitian ini dilaksanakan dengan jumlah 27 anak. Instrumen penelitian ini menggunakan alat bantu pedoman observasi dan pedoman dokumentasi.

Hasil penelitian menyimpulkan bahwa : pratindakan penelitian didapatkan hasil 32,22\%, kemudian pada siklus I mengalami peningkatan rata-rata pengembangan motorik kasar mencapai 55.74\% dan siklus II rata-rata pengembangan motorik kasar mencapai 84,44\%. Dengan hasil tersebut menunjukkan bahwa penelitian ini berhasil karena sudah mencapai target indikator penelitian sebesar 75\%.

\section{Kata Kunci: Motorik Kasar, Kegiatan menari}




\section{PENDAHULUAN}

Pendidikan anak usia dini (PAUD) merupakan tingkat pendidikan sebelum jenjang pendidikan dasar dalam bentuk pembinaan yang ditujukan bagi anak dengan rentang usia 4 setengah tahun sampai umur 6 tahun, dalam prosesnya dilakukan dengan pemberian rangsangan pendidikan untuk membantu pertumbuhan dan perkembangan jasmani dan rohani, tidak lain agar anak memiliki kesiapan untuk memasuki pendidikan lebih lanjut, yang diselenggarakan pada jalur formal, nonformal dan informal.

Menurut Undang-Undang No 20 Tahun 2003 pada pasal 1 poin ke 4 tentang Sistem Pendidikan Nasional menyatakan bahwa "pendidikan anak usia dini merupakan upaya pembinaan terhadap anak sejak lahir sampai usia 6 tahun yang dilakukan melalui pemberian rangsangan pendidikan untuk membantu pertumbuhan dan perkembangan jasmani rohani agar anak memiliki kesiapan dalam memasuki pendidikan lebih lanjut. (Shanie, A., \& Clarita, 2021) Pemenuhan aktivitas-aktivitas kemandirian, aktivitas bermain, dan keterampilan dalam pendidikan taman kanak-kanak akan maksimal dan baik jika diiringi dengan perkembangan motorik kasar yang baik. Melalui keterampilan motorik yang baik, khususnya motorik kasar anak dapat melakukan aktivitas mandirinya dengan baik, dapat melakukan gerakan-gerakan permainan seperti berlari, melompat, dan dapat melakukan keterampilan berolahraga dan ketrampilan baris-berbaris yang diajarkan dalam pendidikan taman kanak-kanak yang diikutinya. Jika keterampilan motorik kasar anak kurang baik, tidak hanya pemenuhan kemandirian aktivitas yang terlambat, akan tetapi hal itu juga berdampak kepada perkembangan anak yang lain seperti aktivitas sosial, perkembangan konsentrasi, dan perkembangan motorik planning yang kurang baik.

Kesadaran akan arti penting generasi penerus yang berkualitas mengharuskan kita serius membekali anak dengan pendidikan yang baik agar dirinya menjadi manusia seutuhnya dan menjadi generasi yang lebih baik dari pendahulunya (Mursid, 2015). Belajar adalah suatu proses usaha yang dilakukan seseorang untuk memperoleh suatu perubahan tingkah laku yang baru secara keseluruhan (Slameto, 2010). 
Motorik merupakan perkembangan pengendalian gerakan tubuh melalui kegiatan yang terkoordinir antara susunan saraf, otot, otak dan spinal cord. Kemampuan motorik kasar sangat penting agar anak bisa meningkatkan keterampilan tubuh dan cara hidup sehat sehingga dapat menunjang pertumbuhan jasmani yang optimal. Pengembangan keterampilan motorik kasar meliputi seluruh tubuh atau bagian tubuh yang melibatkan bermacam koordinasi kelompok otot-otot tertentu. Pada umumnya anak usia 4-6 tahun anak mampu menggerakkan anggota tubuhnya untuk melakukan aktivitas fisik secara terkoordinasi baik untuk kecepatan, dan kelincahan. Akan tetapi pada kenyataanya tidak semua anak dapat berkembang sesuai dengan tahapannya. Hal tersebut dikarenakan berbagai faktor yang mempengaruhi anak yakni faktor kesehatan anak, status gizi anak, dan lain-lain.

Menurut Peraturan Menteri Pendidikan dan Kebudayaan Republik Indonesia Nomor 137 Tahun 2014 tentang Standar Pendidikan Anak Usia Dini, indikator perkembangan motorik kasar anak TK kelompok B mencakup kemampuan anak dalam: 1) Melakukan gerakan tubuh secara terkoordinasi untuk melatih kelenturan, keseimbangan, dan kelincahan, 2) Melakukan koordinasi gerakan mata dan kaki, 3) Melakukan permainan fisik dengan aturan, 4) Terampil menggunakan tangan kanan dan kiri, 5) Melakukan kegiatan kebersihan diri.

Upaya yang telah dilakukan oleh penelitian lainnya diantaranya yaitu melalui kegiatan melambungkan dan menangkap (Alim, 2015). Sehubungan dengan hal tersebut maka anak perlu mendapat stimulasi perkembangan motorik anak yang tepat. salah satunya melalui kegiatan menari.

Berdasarkan hal tersebut, perlu mendapat perhatian yang lebih agar anak didik kita dapat menguasai seluruh aspek perkembangan secara optimal dengan baik. Oleh karena itu peneliti segera menindak lanjuti yaitu di dalam pembelajaran untuk mengembangkan motorik kasar anak perlu suatu metode atau cara unik, inovatif dan kreatif serta menyenangkan, dengan kegiatan menari. 


\section{KAJIAN TEORI}

\section{A. Pengertian Motorik Kasar dan Kegiatan Menari \\ 1. Pengertian Motorik Kasar}

Motorik kasar dapat diartikan Kemampuan gerak tubuh yang menggunakan otot-otot besar, sebagian besar atau seluruh anggota tubuh. Anak senang sekali untuk bermain, dalam pikiran anak adalah bermain (Febriani, E. 2016). Motorik kasar diperlukan agar anak dapat duduk, menendang, berlari, naik turun tangga dan sebagainya. Untuk merangsang motorik kasar anak dapat dilakukan dengan melatih anak untuk meloncat, memanjat, memeras, bersiul, membuat ekspresi muka senang, sedih, gembira, berlari, berjinjit, berdiri diatas satu kaki, berjalan di titian dan sebagainya. Motorik kasar harus selalu diberikan stimulus agar mampu berkembang dengan baik (Wahyuni, I. W., \& Muazimah, A. 2020)

Pengembangan gerakan motorik kasar juga memerlukan koordinasi kelompok otot-otot anak yang tertentu. Keterampilan motorik ini berkaitan erat dengan kegiatan fisik anak (Rini, N. S. 2009) Dalam perkembangannya, motorik kasar berkembang lebih dahulu dari pada motorik halus. Hal ini dapat terlihat saat anak sudah dapat menggunakan otot-otot kakinya untuk berjalan sebelum ia dapat mengontrol tangan dan jari-jarinya menggunting dan meronce. Anak dengan kemampuan motorik kasar yang baik, maka beriringan dengan perkembangan mental yang baik pula (Hidayanti, M. 2013).

Perkembangan fisik anak - anak dimulai dari masa bayi sampai masa anak-anak relatif seimbang. Peningkatan berat badan anak lebih banyak dari pada panjang badannya. Peningkatan berat badan anak terjadi terutama karena bertambahnya ukuran sistem rangka, otot dan ukuran beberapa organ tubuh lainnya (David, 1980).

Pertumbuhan dan perkembangan fisik pada masa anak-anak terdiri dari pertumbuhan dan perkembangan motorik kasar dan motorik halus. Faktor-faktor yang mempengaruhi motorik kasar yaitu genetic, pre natal, post natal, simulasi dan riwayat kelahiran premature (Ananditha, A. C. 2017).Perkembangan motorik kasar merupakan perkembangan anak menggunakan seluruh anggota badan (otot - otot besar) untuk melakukan sesuatu. Di dalam Al 
Qur'an dijelaskan mengenai perkembangan fisik dalam Al Qur'an Surah Ar-Rum ayat 54 sebagai berikut:

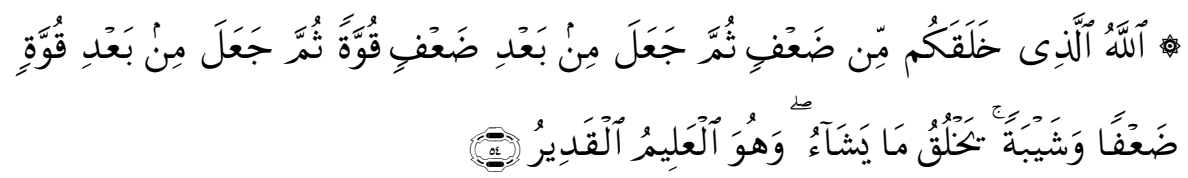

Allah, Dialah yang menciptakan kamu dari keadaan lemah, kemudian Dia menjadikan (kamu) sesudah keadaan lemah itu menjadi kuat, kemudian Dia menjadikan (kamu) sesudah kuat itu lemah (kembali) dan beruban. Dia menciptakan apa yang dikehendaki-Nya dan Dialah Yang Maha Mengetahui lagi Maha Kuasa.( Surah Ar-Rum: 54)

Ayat ini menjelaskan perkembangan fisik manusia terjadi melalui beberapa tahap kejadian, menjadi seorang anak, lalu menjadi dewasa dan menjadi tua. Pada masa kanak-kanak perkembangan fisik terjadi pada semua bagian tubuh dan fungsinya. Seperti perkembangan kemampuan motoriknya, khususnya motorik kasarnya yang berupa kemampuan mengubah beragam posisi tubuh dengan menggunakan otot - otot besar.

Perkembangan fisik motorik anak akan mempengaruhi disetiap kehidupan sehari-hari anak, jika perkembangan fisik motorik anak berkembang dengan baik, perkembangan lainnya pun akan berkembang dengan baik pula. Terutama dalam hal motorik kasar, segala sesuatu yang dilakukan anak dimulai dari motorik kasarnya. Anak dapat merangkak, berjalan, berlari, melompat, dan sebagainya (Suyadi, 2014)

\section{Pengertian Menari}

Menari berasal dari kata dasar tari. Tari adalah gerak tubuh secara berirama yang dilakukan di tempat dan waktu tertentu untuk keperluan pergaulan, mengungkapkan perasaan, maksud, dan pikiran. Bunyi-bunyian yang disebut musik pengiring tari mengatur gerakan penari dan memperkuat maksud yang ingin disampaikan.

Tari adalah gerak dari seluruh anggota badan yang selaras dengan bunyi musik (gamelan), diatur oleh irama yang sesuai dengan maksud dan tujuan dalam menari. Pengertian menari adalah ungkapan perasaaan atau ekspresi jiwa manusia yang diungkapkan 
melalui gerak yang ritmis dan indah. Menari berarti memainkan tari (menggerak-gerakkan tubuh dengan irama). Menari merupakan keterampilan khusus, bahkan bakat itu menentukan kualitas tarinya. Namun, demikian bukan berarti bahwa seseorang yang kurang berbakat tidak mempunyai peluang untuk menjadi penari yang berkulitas. Karena semua ketrampilan bisa dipelajari, dilatih, dan dibiasakan. Fungsi seni rupa yaitu sebagai mitologis, religius, edukasi, psikologis, ekspresi personal, sosial, ekonomis, komunikatif, dan budaya (Pekerti, 2013).

Bahan baku utama dari seni tari adalah gerak. Karakteristik gerak anak pada umumnya mereka dapat melakukan kegiatan kegiatan pergerakan menirukan. Apabila ditunjukkan kepada anak didik suatu action itu sampai pada yang diamati, maka ia akan mulai membuat tiruan terhadap action itu sampai pada tingkat ototototnya dan dituntut oleh dorongan kata hati untuk menirukannya. Pengajaran seni tari juga membutuhkan metode yang tepat untuk anak, agar dalam pelaksanaanya, anak-anak dapat mengikuti gerakan tari dengan bahagia dan semangat, begitu juga dengan tujuan dari pendidikan seni tari bisa tercapai dengan baik (Mulyani, 2017).

\section{Tari dan Anak Usia Dini}

Padahakikatnya anak merupakan pribadi yang unik dan menarik. Tak jarang, terkadang banyak dari orangtua menjadikan anaknya sebagai hiburan setelah seharian beraktivitas. Seorang anak tentunya memiliki kebutuhan serta kemampuan yang berbeda dengan orang dewasa. Salah satu bentuk dan kemampuan anak yang khas tersebut adalah mengekspresikan diri, Dengan disadarinya kebutuhan anak untuk mengekspresikan rasa termasuk mengekspresikan rasa seni (keindahan) yang anak miliki (Mulyani, 2017).

keindahan (seni), mendorong pendidik (guru) untuk menyediakan fasilitas berupa kegiatan yang memungkinkan anak untuk secara lancar dapat mengungkapkan rasa keindahan, serta dapat mengapresiasikan gejala keindahan yang ada disekelilingnya. Kegiatan untuk memfasilitasi anak inilah yang ditawarkan oleh karena itu, pendidikan seni dalam konteks ini, hadir untuk memenuhi kebutuhan anak yang paling asasi yang tidak mampu diemban atau digantikan oleh kegiatan lain. Kegiatan dalam seni 
tari merupakan salah satu sarana pendidikan yang dapat mengembangkan kepribadian anak lebih positif (Kusumastuti, E. 2004).

Seni tari sebagai bagian dari pendidikan seni, hakikatnya berfungsi untuk membentuk karakter, memperhalus budi pekerti manusia, sehingga sebagai warga masyarakat kelak, di samping kecerdasan dan pengetahuan yang diperoleh di bangku sekolah, mereka ditempa pula kepribadian dan sikapnya untuk dapat merasakan dan menghargai nilai-nilai keindahan dan keseluruhan kehidupannya. Pembelajaran seni untuk AUD sangat cocok meskipun setiap anak memiliki kemampuan motorik yang berbeda (Sutini, A. 2012). Dengan demikian, tujuan pendidikan seni di PAUD, adalah agar anak-anak memiliki pengetahuan, nilai dan sikap serta keterampilan yang memadai sesuai dengan tingkat perkembangannya. Melalui pendidikan seni tari, anak-anak diharapkan mampu mengungkapkan ide-ide, imajinasi, dan fantasinya secara kreatif. Peningkatan keterampilan ini salah satunya dapat melalui pelatihan (Sundari, R., \& Zahro, 2021).

Gerak sebagai bagian utama dari tari, digunakan sebagai media untuk mengungkapkan ide dari apa yang mereka pikirkan dan rasakan. Strategi dalam pembelajaran seni tari tentu sangat dibutuhkan usaha yang optimal (Setiawan, A. 2014). Tentunya, mengungkapkan perasaan, pikiran, dan gagasan anak pada sebuah gerak kreatif memang tidaklah mudah. Dalam mengembangkan imajinasi anak akan gerak, maka diperlukan suatu komunikasi secara intens, yang dapat memberikan kesempatan bagi anak-anak mengungkapkan ekspresi-ekpresi gerak secara wajar. Pengalaman berekplorasi tersebut, memungkinkan anak-anak untuk menemukan sesuatu yang menarik, sehingga ia dapat mengetahui bagaimana bergerak, mempergunakan gerak, serta mengembangkan kemampuannya melalui simbol-simbol ekspresi yang mereka lihat, dengar, dan rasakan. Pembelajaran tari juga dapat berfungsi untuk meningkatkan pemahaman terhadap lingkungan, contohnya dalam tari kreatif (Yulianti, R. 2016).

Walaupun anak-anak mempunyai keterbatasan dalam melihat dan memaknai sesuatu yang ada sekelilingnya, ketika dituangkan dalam sebuah gerakan yang kreatif. Namun, harus dipahami bersama, setiap anak mempunyai potensi kreatif dalam dirinya. Kekreatifan anak-anak bisa tumbuh dan berkembang dengan 
bantuan dari para guru untuk terus selalu membimbingnya, mendorong atau merangsang daya ciptanya, mengarahkan serta membantu dalam mengungkapkan ide kreativitasnya.

Hal ini karena pembelajaran seni tari sejatinya tidak hanya bertujuan untuk mengembangkan seni itu sendiri, tetapi juga untuk mengembangkan potensi dan dimensi lain yang dimiliki anak. Karena dalam pembelajaran tari, berbagai dimensi keilmuan tercakup di dalamnya. Cakupan itu antara lain, berhitung, membaca, bercerita, gerak, nyanyian, serta nilai-nilai kehidupan seperti kedisiplinan, ketekunan, kerja sama dalam kelompok, dan lainnya.

Selain tujuan kegiatan dan karakteristik anak itu sendiri, menurut Moeslichatoen (Moeslichatoen, 2004), sedikitnya ada empat faktor lain yang ikut berpengaruh dalam pemilihan metode, yakni sebagai berikut:

a) Tempat kegiatan tersebut dilakukan, di dalam atau di luar kelas.

Gordon dan Brown dalam bukunya Moeslichatoen (Moeslichatoen, 2004), menjelaskan bahwa ada kegiatan yang cocok dilakukan di dalam kelas, tetapi selain itu ada kegiatan lainnya yang cocok dilakukan di luar kelas.

b) Keterampilan yang hendak dikembangkan

Keterampilan yang hendak dikembangkan dalam hal ini melalui berbagai program kegiatan dapat dibedakan atas pengembangan keterampilan kognitif, bahasa, kreativitas, motorik, dan emosi, serta pengembangan sikap hidup. Untuk mengembangkan berbagai macam keterampilan itu, guru harus memilih metode yang paling cocok.

c) Tema yang dipilih dalam kegiatan tersebut

Tema yang dipilih hendaknya tema-tema yang menarik, menantang, dan bermakna bagi anak. Untuk memenuhi kriteria-kriteria tersebut, sebaiknya tema tersebut berkaitan langsung, ada kaitannya dengan anak.

Tari adalah gerak dari seluruh anggota badan yang selaras dengan bunyi musik (gamelan), diatur oleh irama yang sesuai dengan maksud dan tujuan dalam menari. Beberapa definisi dari para ahli (Setyobudi, 2007), diantaranya :

a) B.P.H. Soeryodiningrat 
Tari adalah gerak dari seluruh anggota badan yang selaras dengan bunyi musik (gamelan), diatur oleh irama yang sesuai dengan maksud dan tujuan dalam menari.

b) Drs. Soedarsono

Tari adalah ekspresi jiwa manusia yang diungkapkan dengan gerak ritmis yang indah.

c) Raden Mas Wisnoe Wardhana

Dalam bukunya pengajaran Tari : Tari adalah ekspresi gerak dengan media tubu,h manusia.

d) Drs. Sudharso Pringgo Broto

Tari adalah keteraturan bentuk gerak tubuh dalam ruang

e) Drs. S. Humardhani

Tari adalah ungkapan bentuk-bentuk gerak ekspresif yang indah dan ritmis

Sedangkan definisi tari menurut beberapa ahli yang ditulis oleh Kusnadi (Helmawati, 2018), diantaranya : Tari adalah gerak ritmis (Curt Sacks). Gerak ritmis adalah gerak manusia yang sudah berolah tempo dan dinamikanya. Gerak ritmis tersebut kadang-kadang cepat, kadang-kadang patah-patah, kadangkadang mengalun.

Beberapa metode yang bisa digunakan dalam pembelajaran seni tari di PAUD, yaitu :

1. Metode Bercerita

Bercerita, menurut Gordon dan Browne, merupakan cara untuk meneruskan warisan budaya dari satu generasi ke generasi berikutnya. Selain itu, cerita juga dapat menjadi media untuk menyampaikan nilai-nilai yang berlaku di masyarakat. Seorang "pendongeng" yang baik, akan menjadikan cerita sebagai sesuatu yang menarik dan hidup. Kemudian dari pada itu, keterlibatan anak terhadap cerita akan memberikan suasana yang segar, hidup, menarik dan menjadi pengalaman yang unik bagi anak.

Bercerita juga mempunyai makna yang penting bagi perkembangan anak, karena melalui cerita seorang guru, dapat :

(1) Mengomunikasikan nilai-nilai budaya

(2) Mengomunikasikan nilai-nilai sosial

(3) Mengomunikasikan nilai-nilai keagamaan

(4) Menanamkan etos kerja, etos waktu, dan etos alam 
(5) Membantu mengembangkan fantasi anak

(6) Membantu mengembangkan dimensi kognitif anak

(7) Membantu mengembangkan dimensi bahasa anak

Dalam proses pembelajaran tari, seorang guru, sebaiknya sebelum mengajarkan ragamgerak tari terlebih dahulu harus menceritakan tentang tema tari yang akan dibawakan dan di ajarkan. misal, tema yang akan dibawakan adalah tari bertema hewan misalnya burung, guru bercerita dahulu tentang dunia burung tersebut seperti apa dan bagaimana. Seperti bagaimana cara burung terbang, burung hidup di mana, makanannya apa, dan lain sebagainya. Titikpenekanannya adalah cerita yang dibawakan oleh guru, yang intinya memiliki substansi sebagai pengantar pada gerakan-gerakan tari, juga sebagai sebuah pengalaman belajar bagi anak/peserta didik.

Dengan demikian, pemikiran anak-anak akan terbuka dengan materi yang akan disampaikan. Hal ini akan mempermudah dengan gerakan yang diajarkan, karena sebelumnya anak sudah memahami materi tari. Di sisi lain, kegiatan bercerita juga memberikan pengalaman belajar untuk berlatih pendengaran. Dengan mendengarkan cerita dengan baik, maka anak akan terlatih untuk menjadi pendengar yang kreatif dan kritis. Sebagai pendengar yang kreatif, anak mampu melakukan pemikiran-pemikiran baru berdasarkan apa yang sudah didengarkannya, ditambah dengan pengalaman yang sudah ia rasakan atau informasi yang didapatkan sebelumnya. Oleh karena itu, tidaklah heran jika banyak gerakan-gerakan kreatif dari anak yang spontan, yang salah satu faktornya adalah menjadi pendengar yang kreatif.

2. Metode Bercakap-cakap

Menurut Hildebrand, bercakap-cakap berarti saling mengomunikasikan pikiran dan perasaan secara verbal atau mewujudkan kemampuan bahasa reseptif dan bahasa ekspresif. Selain itu, menurut Gordon dan Browne, bercakap-cakap adalah dialog atau sebagai perwujudan bahasa reseptif dan ekpresif dalam suatu situasi. 
Bercakap-cakap dalam pembelajaran anak usia dini mempunyai posisi paling penting dan strategis. Hal ini karena dengan bercakap-cakap, anak dapat belajar meningkatkan keterampilan berkomunikasi dengan orang lain, meningkatkan keterampilan menyatakan apa yang ia rasakan, dan belajar menyatakan gagasan atau ide. Selain itu, bercakap-cakap juga dapat mengembangkan perkembangan anak, seperti perkembangan kognitif, bahasa, sosial, emosi, dan konsep diri.

Metode bercakap-cakap biasanya dilakukan sebelum dan sesudah pembelajaran tari. Sebelum pembelajaran tari, guru membangkitkan semangat anak-anak dan membuat anak senang dan nyaman dalam proses belajar tari. Karena ada kemungkinan, tidak semua anak suka belajar tari. Oleh karena itu, hal yang pertama kali dilakukan adalah membuat kelas tari menjadi nyaman bagi seluruh individu anak.

Setelah metode tari disampaikan (dengan metode cerita), dan sebelum belajar gerakan tari, guru juga melakukan cakap-cakap terkait materi yang disampaikan. Hal ini, selain untuk melatih keberanian anak berbicara di depan orang banyak, juga untuk mengevaluasi sejauh mana pemahaman anak tentang materi tari yang sudah dijelaskan tersebut. Selain itu, baru kemudian anak-anak belajar gerakan tari. Dengan demikian, diharapkan anakanak yang sebelumnya tidak suka menari, dengan didahului oleh cerita yang menarik, dan merangsang keberanian lewat cakap-cakap, akan timbul dirinya keinginan untuk belajar, walaupun harus dengan penyesuaian yang lama. Tidak sampai di situ, bercakapcakap juga seharusnya dilakukan guru tari setelah pembelajaran tari. Dalam hal ini, lebih menekankan kepada evaluasi gerakan yang sudah diajarkan. "Bagaimana tadi gerakannya, sulit ga?", "Sulitnya di mana?", dan lain-lain.

Secara sekilas, metode berkomunikasi atau bercakap memang terlihat sederhana, tetapi dalam kesederhanaan itulah banyak nilai atau pelajaran yang didapat anak, seperti melatih keberanian mengemukakan pendapat di 
depan orang banyak, melatih kemampuan nalar (kognitif), perkembangan sosial, dan lain-lain.

3. Metode Demontrasi

Dalam menstranfer sebuah materi, apalagi materi seni tari, guru mengalami kesusahan jika hanya menjelaskan secara lisan saja. Dalam hal ini, guru menunjukkan, mengajarkan, dan menjelaskan apa yang sedang dilakukannya (Showing, doing, and telling). Tiga hal tersebut merupakan komponen yang utama dalam metode demontrasi.

Selanjutnya, (Moeslichatoen, 2004) menjelaskan tentang makna demontrasi bagi anak, seperti berikut :

(1) Dapat memperlihatkan secara konkret apa yang dilakukan / dilaksanakan / memperagakan.

(2) Dapat mengomunikasikan gagasan, konsep, ide, dengan peragaan.

(3) Membantu mengembangkan kemampuan mengamati secara teliti dan cermat.

(4) Membantu mengembangkan kemampuan untuk melakukan segala pekerjaan secara teliti, cermat, dan tepat.

(5) Membantu mengembangkan peniruan dan pengenalan secara tepat.

Setelah guru bercerita tentang tema tari, dan kiranya anak sudah memahami materinya, selanjutnya guru mencontohkan gerakan tari. Guru menjelaskan, sambil mencontohkan gerakan kepada anak : "Sekarang perhatikan baik-baik, angkat tangan kanannya, kemudian bengkokkan menyerupai ular, terus kepala ularnya maju tiga kali", lalu anak-anak pun mengikuti gerakan sesuai yang diinstruksikan.

Metode demonstrasi digunakan dalam pembelajaran tari, karena guru akan mengalami kesulitan untuk menjelaskan gerakan-gerakan tari hanya dengan kata-kata saja. Dengan kegiatan demonstrasi, guru dapat meningkatkan pemahaman anak melalui penglihatan dan pendengarannya. Anak diminta untuk memperhatikan dan mendengarkan baik-baik semua keterangan guru, sehingga ia lebih paham tentang gerakan tersebut. Dengan 
demikian, selanjutnya anak dapat meniru bagaimana caranya melakukan gerakan tari seperti yang dicontohkan guru.

Setelah guru mencontohkan gerakan tari, kemudian anak-anak menirukan gerakan tersebut. Dalam meniru gerakan, anak-anak terkadang tidak langsung memahami dengan jelas gerakan tersebut. Oleh karena itu, guru harus senantiasa mengulang-ngulang gerakan, sampai anak paham gerakan satu dengan yang lainnya, juga dengan urutannya. Dalam hal demikian, sejatinya anak sedang dilatih perkembangan kognitifnya.

\section{METODE PENELITIAN}

Pendekatan penelitian yang dilakukan adalah dengan Penelitian Tindakan Kelas (PTK) yang berasal dari bahasa inggris Classroom Action Research yang berarti penelitian yang dilakukan pada sebuah kelas untuk mengetahui akibat tindakan yang diterapkan pada suatu objek penelitian. Tujuan penelitian tindakan kelas ini adalah untuk mengembangkan motorik kasar melalui kegiatan menari pada Kelompok B1 melalui kegiatan menari di RA IMAMA, Kedungpane, Mijen, Semarang Tahun Ajaran 2019/2020. Hakikat dari Penelitian Tindakan Kelas (PTK) merupakan ragam penelitian pembelajaran yang berkonteks kelas yang dilaksanakan oleh guru untuk memecahkan masalah - masalah yang dihadapi oleh guru dan mencobakan hal-hal baru.

Penelitian ini merupakan Penelitian Tindakan Kelas (PTK) yang menggunakan tiga siklus. PTK terdiri atas rangkaian empat kegiatan yang dilakukan dalam siklus berulang. Empat kegiatan utama yang ada pada setiap siklus yaitu: perencanaan (Planning), pelaksanaan (acting), pengamatan (observing), dan refleksi (reflecting). Penelitian dilakukan selama tiga siklus, setiap satu siklus terdapat empat tahapan, yaitu: 1) Perancanaan; 2) Pelaksanaan; 3) Pengamatan; 4) Refleksi.

Subjek penelitian dari penelitian ini adalah anak usia Kelompok B1 RA IMAMA, Kedungpane, Mijen, Semarang Tahun Ajaran 2019/ 2020 yang berjumlah 27 orang, 14 orang laki - laki dan 13 orang perempuan. 


\section{HASIL DAN PEMBAHASAN}

Metode dalam pembelajaran di Pendidikan Anak Usia Dini, mempunyai ciri khas yang sangat berbeda dengan pembelajaran di sekolah dasar dan seterusnya. Oleh karenanya dalam memilih suatu metode yang akan diterapkann dalam program kegiatan anak di PAUD, guru tentunya harus mempunyai alasan yang kuat disertai faktorfaktor yang mendukung pemilihan metode tersebut. Begitujuga halnya dengan pendidikan seni tari. Pengajaran seni tari juga membutuhkan metode yang sesuai dan tepat untuk anak, agar dalam pelaksanaanya, anak-anak dapat mengikuti gerakan tari dengan bahagia dan semangat, begitu juga dengan tujuan dari pendidikan seni tari bisa tercapai dengan baik (Mulyadi, 2017).

Berikut ini hasil pengembangan Motorik Kasar Melalui Kegiatan Menari Di RA Imama Kedungpane Mijen Semarang seperti tersaji dalam table sebagai berikut :

Tabel 1. Rekapitulasi Pengembangan Motorik Kasar Siklus

1

\begin{tabular}{|c|c|c|c|c|}
\hline \multirow[t]{2}{*}{ No. } & \multirow[t]{2}{*}{ Kriteria Penilaian } & \multicolumn{3}{|c|}{ Pertemuan } \\
\hline & & 1 & 2 & 3 \\
\hline 1. & $\begin{array}{l}\text { Kemampuan anak } \\
\text { menggerakkan tubuh } \\
\text { secara terkoordinasi }\end{array}$ & $35,16 \%$ & $49,07 \%$ & $56,48 \%$ \\
\hline 2. & $\begin{array}{l}\text { Kemampuan anak } \\
\text { meniru gerakan }\end{array}$ & $43,52 \%$ & $51,85 \%$ & $60,19 \%$ \\
\hline 3. & $\begin{array}{lr}\text { Kemampuan } & \text { anak } \\
\text { mengikuti } & \text { iringan } \\
\text { music } & \\
\end{array}$ & $40,74 \%$ & $47,22 \%$ & $52,78 \%$ \\
\hline 4. & $\begin{array}{l}\text { Kemampuan anak } \\
\text { melenturkan gerakan } \\
\text { tangan kanan dan kiri }\end{array}$ & $43,52 \%$ & $45,37 \%$ & $57,41 \%$ \\
\hline 5. & $\begin{array}{l}\text { Kemampuan anak } \\
\text { menjaga kebersihan } \\
\text { diri }\end{array}$ & $39,81 \%$ & $46,29 \%$ & $51,85 \%$ \\
\hline \multicolumn{2}{|c|}{ Rata-rata } & $40,55 \%$ & $47,96 \%$ & $55,74 \%$ \\
\hline
\end{tabular}




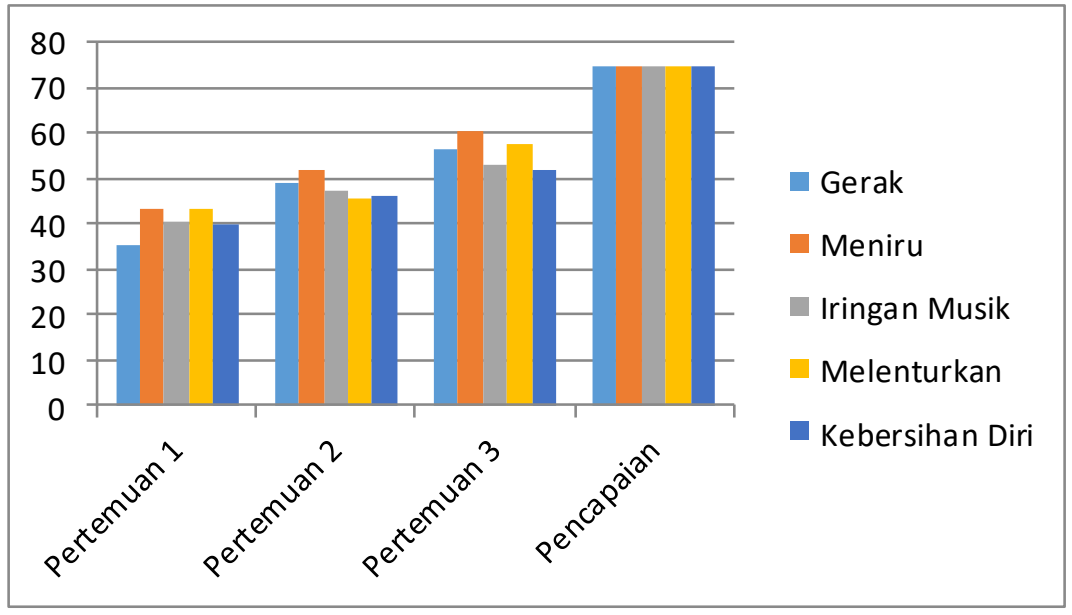

\section{Grafik 1.1 Persentase Pengembangan Motorik Kasar Siklus 1}

Perolehan persentase tersebut belum dapat dikatakan berhasil karena hasil belum mencapai pada angka persentase keberhasilan yaitu sebanyak 75\% dari indikator pencapaian. Untuk itu peneliti perlu melakukan penelitian kembali pada siklus II.

\section{Tabel 2. Rekapitulasi Hasil Observasi Siklus II Pertemuan 1,2, dan} 3

\begin{tabular}{|l|l|c|c|c|}
\hline No. & \multirow{2}{*}{ Kriteria Penilaian } & \multicolumn{3}{|c|}{ Pertemuan } \\
\cline { 2 - 5 } & & 1 & 2 & 3 \\
\hline 1. & $\begin{array}{l}\text { Kemampuan anak } \\
\text { menggerakkan tubuh } \\
\text { secara terkoordinasi }\end{array}$ & $70,37 \%$ & $72,22 \%$ & $81,48 \%$ \\
\hline 2. & $\begin{array}{l}\text { Kemampuan anak } \\
\text { meniru gerakan }\end{array}$ & $75,00 \%$ & $76,85 \%$ & $89,81 \%$ \\
\hline 3. & $\begin{array}{l}\text { Kemampuan anak } \\
\text { mengikuti iringan } \\
\text { musik }\end{array}$ & $68,52 \%$ & $74,07 \%$ & $79,63 \%$ \\
\hline 4. & $\begin{array}{l}\text { Kemampuan anak } \\
\text { melenturkan gerakan } \\
\text { tangan kanan dan kiri }\end{array}$ & $62,04 \%$ & $66,67 \%$ & $84,26 \%$ \\
\hline 5. & $\begin{array}{l}\text { Kemampuan anak } \\
\text { menjaga kebersihan } \\
\text { diri }\end{array}$ & $54,63 \%$ & $62,04 \%$ & $87,04 \%$ \\
\hline \multicolumn{2}{|l|}{ Rata-rata } & $66,11 \%$ & $70,37 \%$ & $84,44 \%$ \\
\hline
\end{tabular}




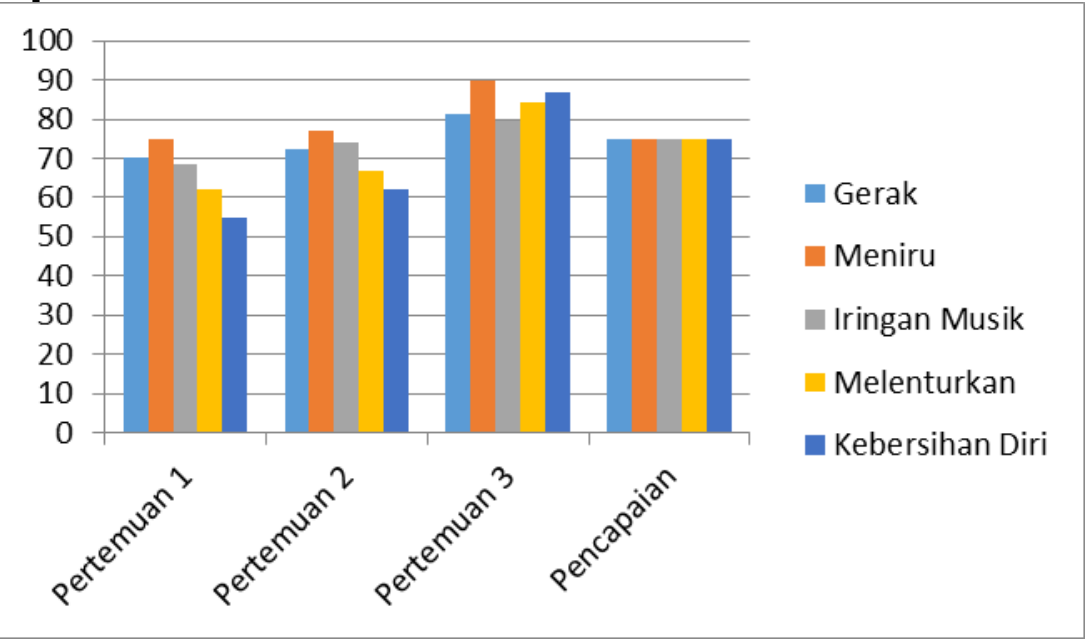

\section{Grafik 2. Persentase Pengembangan Motorik Kasar Siklus II}

Dari grafik di atas menunjukkan bahwa motorik kasar anak di RA IMAMA mengalami pengembangan serta pencapaian indikator yang berhasil pada siklus II mencapai $84,44 \%$. Hasil siklus II juga lebih baik dibandingkan dengan siklus $1 .:$

\section{SIMPULAN}

Berdasarkan hasil analisis data yang dilakukan secara kolaboratif antara guru dan peneliti, dapat disimpulkan bahwa kegiatan menari dapat mengembangkan kemampuan motorik kasar pada kelompok B1 di RA IMAMA Kedungpane, Mijen, Semarang. Upaya ini dapat dilihat dari adanya peningkatan ratarata persentase pengembangan motorik kasar pada anak, yang mana pada pratindakan penelitian didapatkan hasil $32,22 \%$, kemudian pada siklus I mengalami peningkatan rata-rata pengembangan motorik kasar mencapai 55.74\% dan siklus II ratarata pengembangan motorik kasar mencapai 84,44\%. 


\section{DAFTAR PUSTAKA}

Alim, M. L. (2015). Upaya Meningkatkan Kemampuan Fisik Motorik Kasar Anak Melalui Kegiatan Melambungkan Dan Menangkap Dengan Berbagai Media Anak Usia Dini Di TK Al-Fajar Pekanbaru. Jurnal Obsesi: Jurnal Pendidikan Anak Usia Dini, 1(2), 83-93.

David, E. B. (1980). Psikologi Perkembangan. Jakarta: Erlangga.

Helmawati. (2018). Mendidik Anak Berprestasi Melalui 10 Kecerdasan.

Bandung: PT Remaja Rosdakarya.

Moeslichatoen. (2004). metode pengajaran di taman kanak-kanak. Jakarta: PT Asdi Mahasatya.

Mulyadi, N. (2017). Pengembangan Seni Anak Usia Dini. Bandung: PT Remaja Rosdakarya.

Mursid. (2015). Belajar dan Pembelajaran PAUD. Bandung: Remaja Rosdakarya.

Pekerti, W. (2013). Metode Pengembangan Seni. Tangerang Selatan: Universitas Terbuka.

Setyobudi, D. (2007). Seni Budaya untuk SMP Kelas VII. PT. Gelora Aksara Pratama.

Slameto. (2010). Belajar dan Faktor-faktor yang mempengaruhinya. Jakarta: Rineka Cipta.

Shanie, A., \& Clarita, . (2021). Meningkatkan kemampuan bicara anak usia dini melalui pembelajaran menggunakan wayang moderen karakter animasi lucu . Journal of Early Childhood and Character Education, 1(1), 01-18.

Sundari, R., \& Zahro, F. (2021). Peningkatan Kreativitas Melalui Pelatihan Finger Painting Bagi Guru PAUD. Journal of Early 
Childhood and Character Education, 1(1), 45-90.

Suyadi. (2014). Teori Pembelajaran Anak Usia Dini Dalam Kajian Neurosains. Bandung: PT Remaja Rosdakarya.

Wahyuni, I. W., \& Muazimah, A. (2020). Pengembangan Motorik Kasar Anak melalui Permainan Tradisional" Tarik Upih" Berbasis Kearifan Lokal. Jurnal Pendidikan Anak Usia Dini Undiksha,8(1), 61-68.

Febriani, E. (2016). Upaya Meningkatkan Pengembangan Motorik Kasar (Melompat) Anak Melalui Permainan Lompat Tali Pada Kelompok B TK Al-Hidayah Palaosan Tahun Pelajaran 20152016. Prosiding Ilmu Pendidikan, 1(2).

Hidayanti, M. (2013). Peningkatan kemampuan motorik kasar anak melalui permainan bakiak. Jurnal Pendidikan Usia Dini, 7(1), 195200.

Ananditha, A. C. (2017). Faktor-faktor yang berhubungan dengan perkembangan motorik kasar pada anak toddler.Jurnal Keperawatan Muhammadiyah, 2(1), 40-8.

Rini, N. S. (2009). Hubungan Pengetahuan lbu Tentang Perkembangan Anak Dengan Perkembangan Motorik Kasar Dan Motorik Halus Anak Usia 4-5 Tahun Di TK Aisyiyah Bustanul Athfal 7 Semarang. FIKkeS, 2(2).

Kusumastuti, E. (2004). Pendidikan seni tari pada anak usia dini di taman kanak-kanak tadika puri cabang erlangga semarang sebagai proses alih budaya. Harmonia: Journal of Arts Research And Education, 5(1).

Sutini, A. (2012). Pembelajaran Tari Bagi Anak Usia Dini. Cakrawala 


\section{Mursid Mursid, Syafa'atun Nabilah}

Dini: Jurnal Pendidikan Anak Usia Dini, 3(2).

Setiawan, A. (2014). Strategi Pembelajaran Tari Anak Usia Dini. Jurnal Pedagogi, 1(1), 1-16.

Yulianti, R. (2016). Pembelajaran tari kreatif untuk meningkatkan pemahaman cinta lingkungan pada anak usia dini. JPKS OJurnal Pendidikan dan Kajian Seni), 1(1). 